\title{
GREGORY HUTCHINSON
}

\section{Space and text worlds in Apollonius*}

\author{
INTRODUCTION
}

Space has become a major area of interest in the study of classical literature, much more so than when the first version of this piece was composed. Valuable work has been done on space in Apollonius. This piece seeks to advance the exploration of space in Apollonius (and other authors) by looking more closely at the interaction of space and minds. To do so, it will draw on some elements of text world theory, but will give them a more spatial twist. Since discussion of Apollonius has concerned itself particularly with geography and with the relation of Greeks and others, relatively little will be said on larger spaces; smaller spaces have much to offer. ${ }^{1}$

\footnotetext{
* I am grateful to Dr E. Papadodima for the opportunity to include this chapter. In 2018 I gave a talk at the Academy of Athens on motion in Greek and Latin epic; but it overlapped with a book I am writing on motion in classical literature. Instead, I have been invited to include the present piece; it was originally written ten years ago for a joint volume that did not materialize, but it has been reconsidered and updated. It had benefited from the encouragement and comments of Professor G. B. D’Alessio and Dr V. Cazzato.

${ }^{1}$ On space in Apollonius see the important and lively book of Thalmann (2011); it is concerned above all with Greek and foreign cultures, but domestic and social aspects enter in too. See also Danek (2009), André (2012) and Klooster (2012); on geographical aspects see, among other works, Meyer (2008), Hunter (2008a) and (2008b) 71824, and also Nishimura-Jensen (2000). On space and literature see Chatman (1978) 96-107; Hoffmann (1978); Kestner (1978); Bridgeman (2007); Bal (2009) 133-45, Tally (2013). For Greek literature see De Jong (2012); Gilhuly and Worman (2014), and also Lowe (2000) and Purves (2010); for Latin see Fitzgerald and Spentzou
} 
'Space' as an idea like 'time' is not much in evidence in classical literature (but note Plat. Tim. 52a9-b1, d2-4). ${ }^{2}$ It hardly qualifies as a theme in Apollonius; rather it is an area to be considered in analysing the poem. Various post-classical ideas of space as an entity could help our conceptions: especially relevant is Kant's notion of space as a mental framework for our experience, that is, apparent data from our senses. ${ }^{3}$ This notion leads on to the meaningful interpretation and structuring of space by humans: something that has much concerned archaeologists, ancient historians, art historians, geographers, and others. ${ }^{4}$ It is not especially helpful for our purposes to distinguish, after Tuan, between 'space' and 'place': 'space' being more general, although constructed, and a 'place' being somewhere that particular humans have made their own, and have connections with. ${ }^{5}$ That specific opposition would sometimes be

(2018), and note Hutchinson (2013) 295-321, and (2010). For works on individual authors cf. Riggsby (2009); Stackelberg (2009); Clay (2011); Leontaridou (2012); Tsagalis (2012); Purves (2014); Hutchinson (2015) (further on Virgil, Mills (1983), Jenkyns (1998)); Oikonomopoulou (2017) (and the whole volume Georgidou and Oikonomopoulou (2017)).

${ }^{2}$ For ancient philosophical concepts of space (or not) see Morison (2002); for some modern discussion, Casati and Varzi (1999). On the connection of space and values, see Rosen and Sluiter (2006).

${ }^{3} \mathrm{KdrV}$ A 22-30/B 37-45 (Akademieausgabe III 51-7, IV 31-5). Bridges between Kant and Einstein: e.g. Hartmann (1974) on Novalis.

\footnotetext{
${ }^{4}$ For geography cf. recently e.g. Yuan (2018); for ancient history e.g. de Angelis (2010).

${ }^{5}$ See Tuan (1977).
} 
useful in looking at the Argonautica, sometimes not; it will be better to approach the construction of space more flexibly.

Some fundamentals are nicely illustrated by a papyrus of a rhetorical text-book (P. Oxy. LXII 4855 [3 $3^{\text {rd }}$ cent. AD] col. i 16-17): an orator's treatment of the man who strikes his father

will be affected by place. Was the deed done in a field (space without visibility or significance), or in the agora (public and visible space), or in the father's own house (private space, with moral and familial meaning)? The subtleties with which space can be used are exemplified by an Attic red-figure cup from the Brygos Painter (signed; Louvre G152, 500-450 BCE, Beazley Archive 203900; fig. 1). In Achilles' hut, the captive Briseis pours wine for old Phoenix. 'Indoors' is indicated, as often, merely by objects on the wall; but these objects, shield and sword, mark a distortion of the ordinary symposium-scene: this one takes place amid war, with only two people. The indoors scene is placed inside the cup; outside is an outdoor scene: the sack of Troy rages, and another old man, Priam, is brutally slain. On the vase space is discreetly invested with point; in the papyrus we see space implicitly divided into basic types (familial, public, etc.). Both vase and papyrus prepare us to approach space in Apollonius.

\section{PARADOXES AND LEVELS OF SPACE}

How meaningful space is in the poem emerges when characters employ it strangely. The narrator presents the Mossynoeci ('tower-dwellers') as curiously reversing 'our' use of inside and outside (2.1015-29): sex outside, justice inside. 'Like pigs' said of the sex (1023 cúcc œ̈c) does not 
suggest a philosophical open-mindedness in the vivacious narrator. ${ }^{6}$ In the very next episode, though, the Argonauts strangely and ingeniously turn the usual open space of their ship into the closed space of a house (2.1058-89). The birds of Ares drop weapon-like feathers from the sky: the Argonauts cover the ship with spears and shields. Similes liken them to a man roofing over a yard in his house with tiles to keep out the rain, and, in a more evocative use of space, to men hearing the hail overhead on the roofs which they have wisely strengthened. Before long the Argonauts come on a primitive temple with no roof (2.1168-76). The text is continually engaged by such issues.

The supreme paradox with the ship comes in book 4. Ships are mobile spaces that carry men over the sea; but in Libya the men are compelled to carry their ship over the dry desert. The paradox is heightened by the oracle that tells them to do this: they must pay a recompense to the

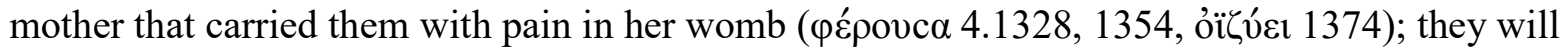

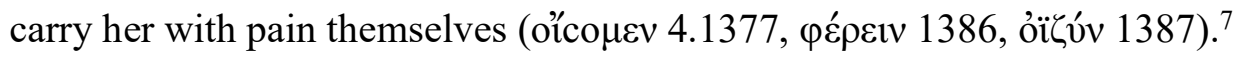

\footnotetext{
${ }^{6}$ Apollonius' chief intertext, Xen. Anab. 5.4.33-4, gives less thematic significance here to space; but cf. 5.4.26. On the Mossynoeci in Apollonius see Schaaf (2014) 133-40 (as to 1017, the explanation cannot be brightly announced after 381B; cf. Matteo (2007) 282-3, 643).

${ }^{7}$ Pind. Pyth. 4.25-7 uses $\varphi \varepsilon \rho$ - 'carry' literally, of this action, but without Apollonius' complexities. On the text in 1373-4 see Hunter (2015), 266. "̌́ $\chi 0 v c \alpha 1373$ of the ship 'having' or 'holding' the men could be seen as ordinary

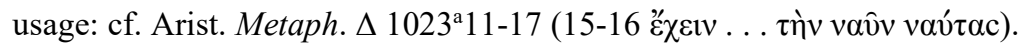


This example introduces us to two distinct sorts of space, the external and the internal, that is, within the body; the two are here connected through metaphor (child-bearing) and through subjective experience (pain). The poem is much concerned with connecting these kinds of space. So when Medea hesitates to talk to her sister about Jason, the narrative creates close parallels between two sorts of fluctuating movement: the first, Medea's movements to the entrance of her sister's bedroom and back; the second, the movement of utterance to her tongue and back to her chest $(3.648-55,681-7){ }^{8}$ In both cases the fluctuation expresses spatially the

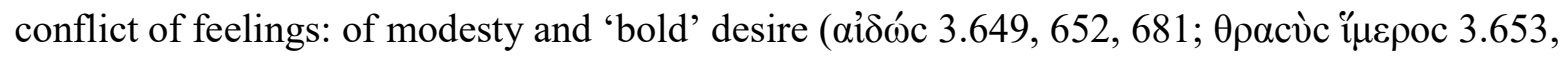

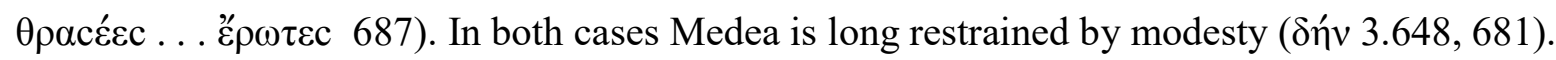
The impulses for the poem's interest in internal space include love-poetry and developments in medicine. These pointed connections between external and internal show a concern in the poem with relating different types of space. The opposition of 'inside' and 'outside' has already been seen with buildings and other structures; in the present passages there are further intricacies, since the external space itself is divided into inside and outside Medea's bedroom (3.650 عै $v \delta o \theta \varepsilon v$ 'from within', 651 cic $\omega$ 'inside'), and within the land of Libya as opposed to the sea (4.1376 ¿้v $\delta \circ \theta_{l}$ ' within' or 'in'). The passages seem to play on these intricacies, with different applications for है $ڤ \delta o-$ near together $(3.650,652,661,4.1376,1385){ }^{9}$

\footnotetext{
${ }^{8}$ Here and elsewhere some spatial aspects of the passages discussed are left out, for clarity of exposition—such as the location and design of the sisters' bedrooms (some points below).

${ }^{9}$ There are complications. $4.1376{ }^{\prime} v \delta \mathrm{o} 0 \theta \mathrm{l}$ is now commonly taken to mean 'towards the interior of' (Hunter (2015),

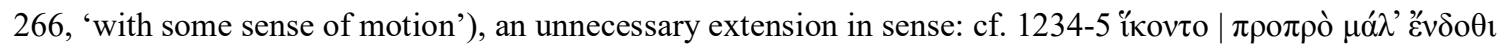

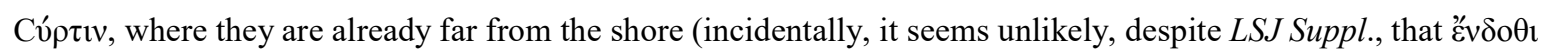




\section{HOUSES}

Houses present one of the most significant forms of organized space; they stand out all the more in a poem with so much travel over sea and on land. ${ }^{10}$ Apollonius' interest extends to their architectural form. At 1.788-80 Jason is led through a beautiful colonnade to meet Hypsipyle. Apollonius for once uses an un-Homeric word ( $\pi \alpha c \tau \alpha$ c $)$, and thus underlines the contemporary character of the structure: porticos and other pillared spaces are common in houses from the fourth century on, as at Olynthus, close to Macedonia. ${ }^{11}$ Equally, the description of Aeetes' palace, with imposing pillars at the front, recalls recent palaces $(3.215-18) .{ }^{12}$

should govern an accusative: the point in the Syrtis where the wind blows them is far inland). In any case, there will

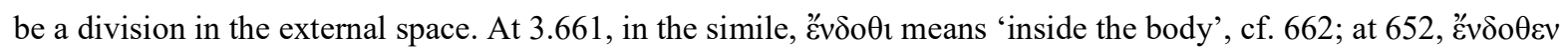
could mean 'within the bedroom' (cf. Hunter (1989), 168), but the ending encourages at least an ambiguity with 'from within her'.

${ }^{10}$ Hoffmann (1978) 492-3 considers a different spatial use of houses in narrative.

${ }^{11}$ Robinson and Graham (1938) 161-6; Hoepfner und Mitarbeiter (1999) 273-4. Cf. also Haagsma (2003) 60, 77-8; Nevett (2010) 45-6, 63-7, 73-9. The word pastas is used in ancient Greek less specifically than by archaeologists. ${ }^{12}$ Brands (1996) 62-5 (including reconstructions of the palace at Vergina). Apoll. fr. 1 Powell seems to show an explicit reference to Corinthian columns: cf. Callix. FGrHist 627 F 1 (38) p. 164.7-8 Jacoby (not 'made by Corinthians': note the particles) and Strabo 4.4.6 198C. lines 35-6 Radt. Other works on houses, including conceptions, besides those in n. 11: Kent (1990), esp. Jameson (1990); Hoepfner and Brands (1996), esp. von Hesberg (1990); Trümper (1998); Souvatzi (2008). 
The poem is alert to its characters' experience of houses' physicality. So blind Phineus, whose house is defiled by Harpies, feels the walls as he staggers out to the threshold of the house (2.197-203). When Medea leaves her house for ever, she kisses the bed and the door of her bedroom and touches its walls (4.26-7). She says a farewell to 'the whole house' (4.32). In the structure of the verse and the sentence, the house is set against the wide space of the sea on

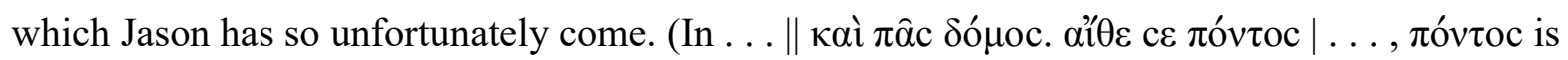
the first weighty word after $\delta$ ó $\mu \mathrm{oc}$, and both are underlined by their position.) The 'foreigner' is

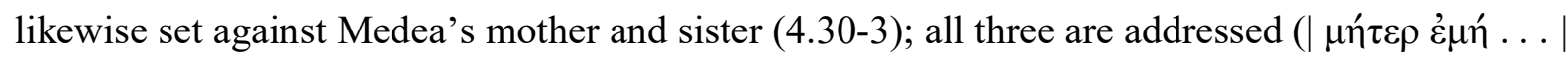

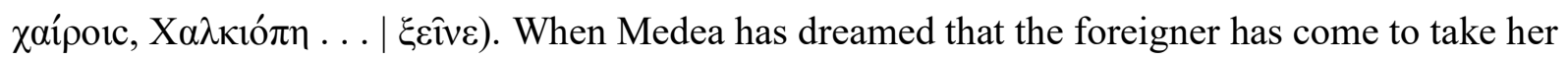
to his house as his wife and that she chooses him over her parents, she awakes in terror, and stares all round ( $\left.\pi \varepsilon \rho^{\prime} \tau^{\prime} \grave{\alpha}_{\mu} \varphi^{\prime} i \varepsilon\right)$ at the walls of her bedroom (3.633-4). Evocation of experienced space again heightens the evocation of emotion and the space's meaning. ${ }^{13}$

\section{TEXT WORLDS AND SIMILES}

\footnotetext{
${ }^{13}$ Medea's dream itself: Perutelli (1994); relation to her mind and to narrative: Saïd (2003) 273-5, Hurst (2003) 244. We now have a parallel (later?) narrative in P. Oxy. LXIX 4712 frr. 1 and 2, which includes Medea's awakening.
} 
Understanding of the role of space can be increased by exploiting the conception of 'text worlds' ${ }^{14}$ A text world is, for our particular purposes, a kind of scene set up within a text. ${ }^{15}$ Each change of viewer, field perceived, mode of perception, time of perceiving, and so forth, requires the marking of a new text world. Thus J. Gavins splits up the opening of A. McCall Smith's The No. 1 Ladies' Detective Agency into different worlds between which the text switches. That opening describes Mma Ramotswe's office at a period in the past, and presently says, 'How could any such list describe what one saw when one looked out from Mma Ramotswe's door? To the front, an acacia tree, the thorn tree which dots the wide edges of the Kalahari ...' This last relative clause moves into a general present and away from Mma Ramotswe and her perspective; it offers a wider vista than 'To the front, an acacia tree'. Gavins accordingly marks at this point a world-switch between two text worlds. In her diagram, each world is enclosed in a box and assigned a number; a line joins the more general world of the relative clause to the world of the initial description. ${ }^{16}$

\footnotetext{
${ }^{14}$ Werth (1999) is the fundamental work; Gavins (2007) is an effective and lucid presentation. On the theory only the minimum of detail necessary for this piece will be given here. No attempt is made to link the kind of space discussed in this piece and 'mental spaces'.

15 The term has a wider scope in text world theory: it there includes any discourse, and need not be much visualized. 'World' will often be used hereafter in the sense of 'text world'.

${ }^{16}$ Gavins (2007) 45-9.
} 
'World' in text world theory is not, one could argue, merely a lifeless technical term. The classic use of 'the world' in German philosophy implies universality and singularity; but a plurality of worlds, as in philosophical possible worlds or parallel universes, holds out to the reader a liberating imaginative appeal. At the same time, 'world' also suggests boundaries; the diagrams of text world theory present the attractive prospect of rigorous demarcation, and of concentrating attention upon distinct entities.

Similes seem to call out for such an approach. So in Apollonius Jason goes to the city on

\section{Lemnos}

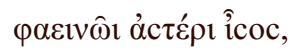

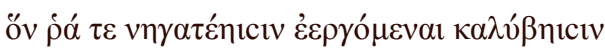

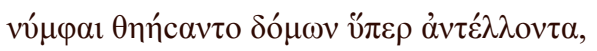

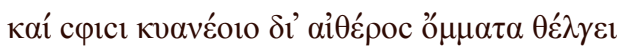

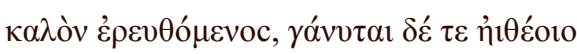

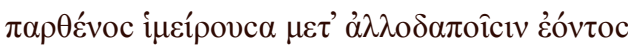

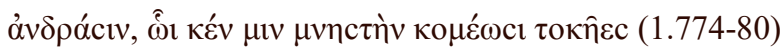

like a bright star, which brides, confined in their newly-made bowers, watch as it rises above their houses, and enchants their eyes in its red beauty through the dark-blue air; and the maiden is happy who desires the young man, now among foreign people, for whom her parents are looking after her as wife. ${ }^{17}$

One could class here as separate worlds: Jason proceeding to the city, the brides watching the star, the maiden seeing the star, her thoughts of the fiancé far away. We can now add in to the

\footnotetext{
17 Cf.on this simile Reitz (1996) 15-19.
} 
text world theory ideas of space such as we have been considering: space and text worlds can enrich each other. ${ }^{18}$ Jason moves towards the human and enclosing space of the city; the enclosed brides look to the distant star in the open sky, with its meaning of nightfall; the girl, implicitly enclosed, links the distant star with her fiancé far away: the reason she is happy must be that the star links the two of them, who can both see it. ${ }^{19}$ The subjective construction of space notably informs this last world; such mental organization of space into meaning will prove important as our discussion proceeds. In the whole simile, target and source domains (tenor and vehicle) are joined by the arrival of the beloved object: Jason; bridegrooms and the betrothed.

When Alcimede embraces her son Jason on his departure, she is likened to a girl

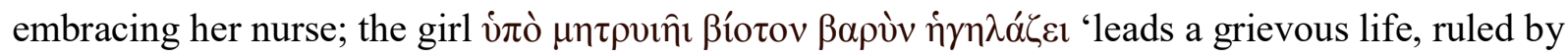
a stepmother' (1.272). The source and target domains of the imagery offer two worlds. These are added to by the worlds which Alcimede's thought generates: she imagines herself in the immediate future left behind $\delta \mu \omega$ ìc ö $\pi \omega c$ 'like a slave' in the empty halls (1.285); she recalls her past glories (1.284-90); she considers how she did not imagine the consequences of Phrixus' flight — this last world an unrealized world (1.290-1). Jason's concern adds still further worlds

\footnotetext{
18 'Space' will include ideas of what happens in and fills the space, especially motion, and objects and people. For motion cf. Hutchinson (2018).

${ }^{19}$ Cf. e.g. Ovid, Tristia 4.3.1-10; Walahfrid, Mon. Hist. Germ. Poetae 2.403 no. 49. Possibly the idea lies in the background of Sappho fr. 96.1-20 Voigt.
} 
for the immediate future: he tells Alcimede to remain in the house 'with your servants' and not be an evil omen to the ship by going there (1.303-4). ${ }^{20}$

Again, space enhances these worlds and their interaction; they go inside and outside houses and bodies. Jason's travelling over the sea is contrasted with Alcimede's remaining in the palace; the contrast gains further force from her subjectivity, and his. The girl's grievous life is

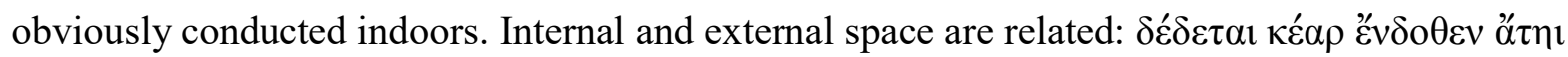
'her heart is bound within her by disaster' as she weeps, and she cannot blurt out as loud a lament as she longs to (1.274-5), after her stepmother's violent insults (1.273). Inner and outer subjection combine. The indoor worlds of the girl and Alcimede ultimately contrast: despite Alcimede's vision of her immediate future 'like a slave' (1.285), she will actually be in charge of

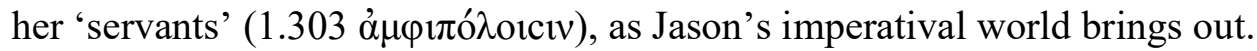

\section{WORLDS OF THE MIND}

We have already seen examples of text worlds constructed by a character who also features in them (an 'enactor'). Text world theorists are interested in such worlds, which happen to play a significant role in Apollonius' poem. They include worlds desired by the characters who

\footnotetext{
${ }^{20}$ These last worlds, which are to be produced and avoided through following commands, could be called 'imperatival'.
} 
mentally conjure them up. Analysis in these terms has been elaborately applied to the ideal wedding envisaged by a celebrity bride-to-be in the magazine $O K !^{21}$

Such wished-for worlds are readily found in the Argonautica, most notably in its second half. Once more the aspect of space repays consideration, both for these worlds and for the narrated worlds they relate to. Jason and Medea achieve their less than perfect wedding in a cave on Corcyra, for pragmatic reasons.

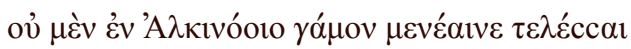

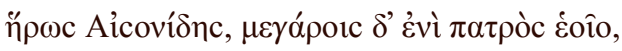

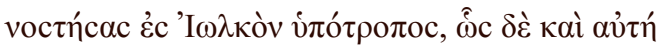

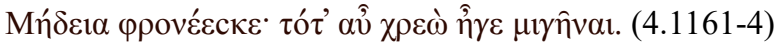

The heroic son of Aeson did not desire to accomplish his marriage in the house of Alcinous, but in the halls of his father, when he returned to Iolcus; such too were Medea's own intentions. But necessity drove them to sleep together then.
}

The imperfect actuality and the imagined worlds are defined by owned domestic and familial

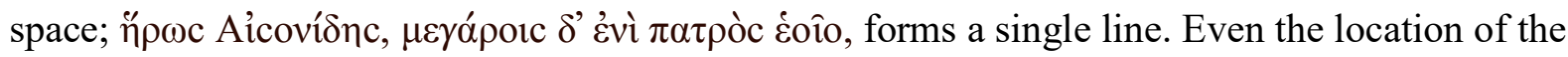
real wedding in Jason's thought ('the house of Alcinous') simplifies the strange reality: a sacred cave once dwelt in by a nymph, somewhere in between an ordinary house and wild nature. It has a vestibule ( $\left.\pi \rho \mu_{0} \lambda \hat{\eta} \imath \mathrm{c} v, 4.1160\right)$; but to it come the nymphs of river, wood and mountain

\footnotetext{
${ }^{21}$ Gavins (2007) 92-6. 'Boulomaic' is the slightly odd term there employed for desired worlds.
} 
(4.1143-52). ${ }^{22}$ After the phrase on necessity, the narrator expands into a global vision of mortals' happiness, always incomplete (4.1165-7); a spatial metaphor sharpens and individualizes the vision: 'we' never step on happiness with our whole foot. Jason and his one sandal (1.7) come to mind. ${ }^{23}$

Earlier, the dialogue between Medea and Jason abounds in imagined worlds; these are built from the basic spatial separation of Greece and Colchis. So Medea at 3.1108-11 creates a future and partly imperatival world: she is telling Jason to bring it about. This world consists of two divided scenes, which are joined by the enactors' subjectivity: she will remember Jason in her parents' home (implied 3.1110), and he is urged to remember her in Colchis. She then joins these conceptions spatially, in two different worlds based on hypothetical wishes: when Jason forgets her, she wants a rumour or a messenger bird to 'come' to her from afar (' better - she wishes to be swept to Iolcus over the sea by winds, and to appear before Jason's eyes (3.1111-17). The separation of space would be annihilated. Jason dismisses these two worlds, and substitutes a climactic vision: Medea in Greece, married to him and honoured by all (3.1120-

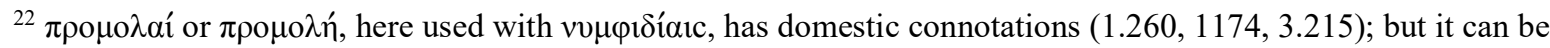
used in a context of nature, cf. e.g. Call. H. 3.99 as against 142. Cf. also Hunter (2015) 239. On caves cf. Ustinova (2009). Depew (2007) gives a metapoetic reading of springs, etc.

${ }^{23}$ For this moment and what precedes it cf. Hutchinson (1988) 133-4; Byre (1997) 70-2. The spatial language in 4.1165-7 makes the subtle conception vivid; it is rewarding to compare the less spatial language used in Leopardi's Operette morali (e.g. Malambruno or Tasso) to convey the starker idea that our state of mind during apparent pleasure and happiness makes them actually unattainable.
} 


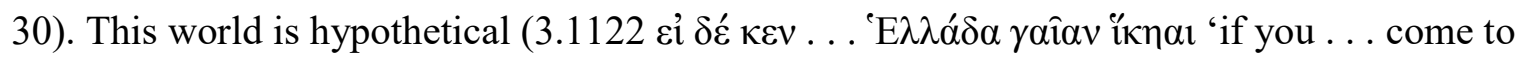
Greece'); it is also an oblique invitation (cf. 3.1133-4). ${ }^{24}$

Before this in the conversation, Medea's worlds have been marked by ignorance about the remote land of Greece which is so important to those worlds. She imagines Jason taking the Fleece there, $\tau \eta \lambda \mathrm{ov} \pi \mathrm{o} \theta \mathrm{l}$ 'somewhere far away' (3.1061). She asks where his home is, and where he is sailing to (3.1071-2) — an interrogative and spatially undefined world. She wonders if he will be going near Orchomenus, which she knows of from her sister's family, or the Aeaean island, which she knows of from her father's (3.1073-4). Jason fills her in on his homeland, and explains that there not even the name of the Aeaean island is to be heard (3.1092-3): such is the spatial distance, of which Medea has no idea (cf. 3.679-80). With even more ignorance and irony, she supposes ( $\pi \mathrm{ov}$ ) that in Greece people care about oaths - as the father whom she knows does not (3.1105-6). Medea will soon learn more about Greece, as we see in a proleptic world presented by the narrator (3.1133-6); she will learn even sooner about Jason and oaths (4.356$62)$.

\section{THE MIND, REALITIES AND A TEENAGER'S BEDROOM}

Reality, and actual movement in space, obtrude on the constructed worlds of characters; but the characters then construct new worlds, shaped by their constructions of space- and their

\footnotetext{
${ }^{24}$ Jason's dismissal of Medea's imaginings recalls Chalciope's (3.711-12): Medea's wild worlds call forth similar strategies from both.
} 
rhetorical purposes. When Medea has fled in the Argo, and her brother has caught up with her, she presents herself to Jason as having left the place she belonged to: her fatherland and the glory

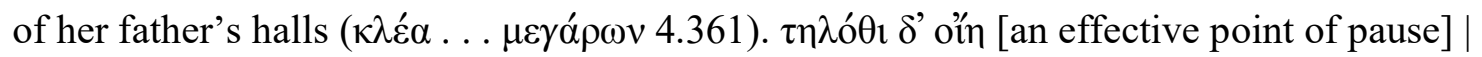

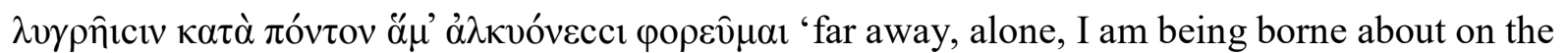
sea, with the sad halcyon birds. ${ }^{25}$ Distance is now part of a present world (contrast 3.1061 $\tau \eta \lambda \mathrm{ov} \pi \mathrm{o} \theta \mathrm{\imath})$; the pathos now lies in her separation from home, not from Jason. Her motion seems a purposeless state, the sea is a place of gloom; she construes herself, from the perspective of her former household, as in solitude. Soon afterwards in the same speech, she presents the motion

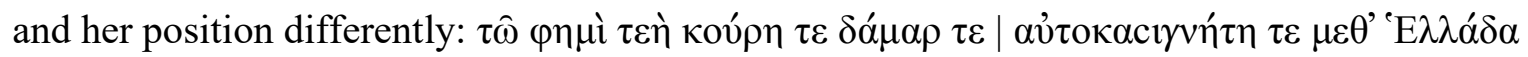
$\gamma \alpha i \alpha \varepsilon^{2} \pi \varepsilon c \theta \alpha \imath$ 'so I say that I am accompanying you to Greece as your daughter, wife, and sister' (4.368-9). Later, in appealing to the Argonauts one by one, she alters her depiction of motion and

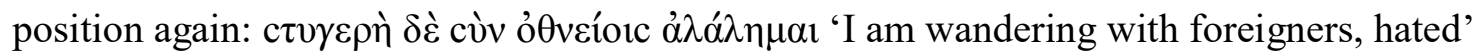
(4.1041). Different people's states of mind affect the worlds she constructs. ${ }^{26}$

${ }^{25}$ Cf. Call. fr. 178.32-3 Harder (89.32-3 Massimilla).

${ }^{26}$ Medea is Helen in the last passage, Andromache in the one before (cf. Hunter (2015) 132-3): cf. Hom. Il. 6.42930, 24.774-5. The word for 'foreigner' here, ò $\theta v \varepsilon \hat{\imath} 0 c$, is never used by Homer. It can convey different types of not belonging, and has irony here, when Medea is about to form a married couple with one of these ỏ $\theta v \varepsilon \hat{o}$. Cf. ỏ $\theta v \varepsilon \hat{o}$ at 3.1144-5 (ambiguously used by Jason); 2.12-14 (Argonauts ethnically foreign to the remote Bebryces), soon followed by 2.235-9 (the remote Phineus is actually part of the same family as his rescuers). On Medea's experience and her presentation of it cf. Hutchinson (2008) 86-9. 
Nor is the spatial contribution of characters to text worlds simply mental. For example, Medea's solitary meeting with Jason in the temple of Hecate is the result of elaborate stagemanagement. Hera, Eros, Chalciope, Argus and others make the meeting happen; the solitude is brought about on the male side by Hera, via Mopsus and a crow (3.927-47), and on the female side by Medea (891-911), who is more of an independent agent than Persephone or Nausicaa (cf. 3.838-42). ${ }^{27}$ The locale is Medea's idea (3.737-8), and springs from her own skills and life-style: she has normally spent her days not in the palace but in the temple of Hecate, whose priestess she is $(3.250-3) .^{28}$

At home, the crucial chest to which she goes for suicidal drugs (3.802-3) reflects her own way of life, and her organization of her substantial bedroom (cf. 3.838-40). ${ }^{29}$ The contents of more ordinary women's rooms also expressed their way of life and their interests: so tomb II from Tumulus A at Aeneia (350-325 BC, Archaeological Museum, Thessaloniki), which recreates a woman's room, includes a pet dove and a box of jewels. ${ }^{30}$ In architecture, Medea's room forms part of the structure created by Aeetes: he has fashioned the text world which the

\footnotetext{
${ }^{27}$ Note Campbell (1983) 61; Hunter (1989) 197; cf. Murgatroyd (2005) 79.

${ }^{28} \mathrm{Cf}$. on this role Schaaf (2014) 151-64.

${ }^{29}$ Cf. Pind. Ol. 6.1-3, perhaps (but cf. Hutchinson (2001) 376).

${ }^{30}$ Vokotopoulou (1996) 195-8.
} 
reader encounters when the Argonauts come to his palace (3.214-48). ${ }^{31}$ Space is fashioned and shaped by people, physically, verbally, mentally, for themselves and for others; the verbal and mental shaping is very much in flux, and even the physical shaping is not free of turns and surprises.

\section{CONCLUSIONS}

Text worlds form only one way of looking at discourse. They make it possible to scrutinize Apollonius more intently, and to see still more; they open ways which go beyond, but intersect with, classic narratology. The system is perhaps less enlightening for texts where relatively fixed worlds are worked out at length (so, in some ways, the Iliad), or indeed for conversations where the worlds are already familiar to the speakers. But for texts like Apollonius, where there is such a constant change of text worlds, the approach holds promise. By bringing it together with the investigation of space, we can give spatial approaches sharper precision, and give text worlds denser substance. The pointedness and intensity of Apollonius' writing can emerge with new force. One useful direction in which the criticism of Apollonius could progress still further is in

\footnotetext{
${ }^{31}$ On the description of Aeetes' place see Thiel (1993) 106-25; see also Klooster (2012) 70-2. Cf. Circe's domain (4.662-84): it shows her power; the text world of her dream perverts her house and undoes her power, but even there she establishes control.
} 
close engagement with what he actually says, with the specifics of his poetry. There certainly remains much to discover in this (inexpensive) form of exploring space.

\section{Bibliography}

Accorinti, D., and Chuvin, P. (eds.) (2003). Des Géants à Dionysos. Mélanges de mythologie et de poésie grecques offerts à Francis Vian. Alessandria.

André, L.-N. (2012). 'Lemnos chez Apollonios de Rhodes : ekphrasis, paysage insulaire et spatialisation', in: Briand, 343-59.

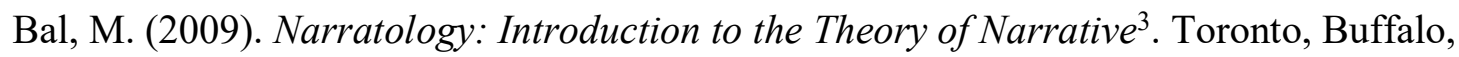
London.

Brands, G. (1996). 'Halle, Propylon und Peristyl — Elemente hellenistischer Palastfassaden in Makedonien', in: Hoepfner and Brands, 62-72.

Briand, M. (ed.) (2012). La Trame et le tableau. Poétiques et rhétoriques du récit et de la description dans l'Antiquité grecque et latine. La Licorne 101, Rennes..

Bridgeman, T. (2007). 'Time and space', in: D. Herman (ed.), The Cambridge Companion to Narrative. Cambridge, 52-65.

Byre, C. S. (1997). 'Suspense in the Phaeacian episode of Apollonius'Argonautica', ICS 22: 6573.

Campbell, M. (1983). Studies in the Third Book of Apollonius Rhodius' Argonautica. Altertumswissenschaftliche Texte und Studien 9. Hildesheim and New York. 
Casati, R., and Varzi, A. C. (1999). Parts and Places: The Structures of Spatial Representation. Cambridge, Mass.

Chatman, S. (1978). Story and Discourse: Narrative Structure in Fiction and Film. Ithaca and London.

Clay, J. Strauss (2011). Homer's Trojan Theater: Space, Vision, and Memory in the Iliad. Cambridge.

Danek, G. (2009). 'Apollonius Rhodius as an (anti-)Homeric narrator: time and space in the Argonautica', in: J. Grethlein and A. Rengakos (eds.), Narratology and Interpretation: The Content of Narrative Form in Ancient Literature. Trends in Classics Suppl. 4. Berlin and New York, 275-91.

de Angelis, F. (ed.) (2010). Spaces of Justice in the Roman World. Columbia Studies in the Classical Tradition, 35. Leiden and Boston.

Depew, M. (2007). 'Springs, nymphs, and rivers. Models of origination in third-century Alexandrian poetry', in: A. Bierl, R. Lämmle, K. Wesselmann (eds.), Literatur und Religion 2. Wege zu einer mythisch-rituellen Poetik bei den Griechen. MythosEikonPoiesis 1,2. Berlin and New York, 141-71.

Fitzgerald, W., and Spentzou, E. (eds.) (2018). The Production of Space in Latin Literature. Oxford.

Gavins, J. (2007). Text World Theory: An Introduction. Edinburgh.

Georgidou, A., and Oikonomopoulou, K. (2017). Space, Time and Language in Plutarch. Millennium-Studien zu Kultur und Geschichte des ersten Jahrtausends n. Chr. 67. Berlin and Boston. 
Gilhuly, K., and Worman, N. (edd.) (2014). Space, Place, and Landscape in Ancient Greek Literature and Culture. Cambridge.

Haagsma, M. (2003). 'The houses of New Halos', in: H. Reinder Reinders and W. Prummel (eds.), Housing in New Halos: a Hellenistic Town in Thessaly, Greece. Lisse, etc., 37-79.

Hartmann, H. (1974). Zur Aktualität der Raum-Zeit-Auffassung des Novalis. Diss. Bonn.

Hesberg, H. von (1996). 'Privatheit und Öffentlichkeit der frühhellenistischen Hofarchitektur', in: Hoepfner and Brands, 84-96.

Hoepfner, W., and Brands, G. (eds.) (1996). Basileia. Die Paläste der hellenistischen Könige. Internationales Symposion in Berlin vom 16. 12. 1992 bis 20. 12. 1992. Mainz am Rhein.

Hoepfner, W., et al. (eds.) (1996-9). Geschichte des Wohnens (5 vols.). Stuttgart.

Hoepfner, W., und Mitarbeiter (1996-9). 'Die Epoche der Griechen', in: W. Hoepfner et al., I 123608.

Hoffmann, G. (1978). Raum, Situation, erzählte Wirklichkeit. Poetologische und historische Studien zum englischen und amerikanischen Roman. Stuttgart.

Hunter, R. L. (1989). Apollonius of Rhodes: Argonautica Book III. Cambridge.

_ (2008a). 'The divine and human map of the Argonautica', On Coming After: Studies in Post-classical Greek Literature and its Reception. Trends in Classics, Suppl. Vol. 3. Berlin, I $257-77$.

— . (2008b). 'The Periegesis of Dionysius and the traditions of Hellenistic poetry', On Coming After: Studies in Post-classical Greek Literature and its Reception. Trends in Classics, Suppl. Vol. 3. Berlin, II 718-34.

— . (2015). Apollonius of Rhodes: Argonautica Book IV (Cambridge). 
Hurst, A. (2003). 'L'énigme dans la trame : quelques allusions chez Apollonios de Rhodes', in: Accorinti and Chuvin, 233-46.

Hutchinson, G. O. (1988) Hellenistic Poetry. Oxford.

—_. (2001). Greek Lyric Poetry: A Commentary on Selected Larger Pieces. Oxford.

_ (2008). Talking Books: Readings in Hellenistic and Roman Books of Poetry. Oxford.

— . (2010). 'Deflected addresses: apostrophe and space (Sophocles, Aeschines, Plautus, Cicero, Virgil, and others)', $C Q$ n.s. 60: 96-109.

_ . (2013). Greek to Latin: Frameworks and Contexts for Intertextuality (Oxford).

— . (2015). 'Space in the Aeneid', in: E. Cingano and H. Günther (edd.), Virgilian Studies. A Miscellany Dedicated to the Memory of Mario Geymonat. Studia Classica et Mediaevalia 10. Nordhausen, 251-86.

— . (2018). 'Motion in Grattius', in: S. J. Green (ed.), Grattius: Hunting an Augustan Poet. Oxford, 135-51.

Jameson, M. (1990). 'Domestic space in the Greek city-state', in: Kent, 92-113.

Jenkyns, R. (1998). Virgil's Experience. Nature and History: Time, Names, and Places. Oxford.

Jong, I. J. F. de (ed.) (2012). Space in Ancient Greek Literature: Studies in Ancient Greek Narrative. Mnemosyne Suppl. 339. Leiden and Boston.

Kent, S. (ed.) (1990). Domestic Architecture and the Use of Space: An Interdisciplinary Crosscultural Study. Cambridge.

Kestner, J. A. (1978). The Spatiality of the Novel. Detroit.

Klooster, J. J. H. (2012). ‘Apollonius of Rhodes', in: De Jong, 55-76.

Leontaridou, D. (2012). 'Poétique de l'espace dans le Philoctète de Sophocle', in: Briand, 273-9.

Lowe, N. J. (2000). The Classical Plot and the Invention of Western Narrative. Cambridge. 
McCall Smith, A. (1998). The No. 1 Ladies' Detective Agency. London.

Matteo, R. (2007). Apollonio Rodio, Argonautiche, Libro II. Introduzione e commento. Lecce.

Meyer, D. (2008). ‘Apollonius as a Hellenistic geographer', in: T. D. Papanghelis and A. Rengakos (eds.), Brill's Companion to Apollonius Rhodius². Leiden, 267-85.

Mills, D. H. (1983). “'Sacred space' in Vergil’s Aeneid', Vergilius 29: 34-46.

Morison, B. C. A. (2002). On Location: Aristotle's Concept of Place. Oxford.

Murgatroyd, P. (2005). Mythical and Legendary Narrative in Ovid's Fasti. Mnemosyne Suppl. 263. Leiden and Boston.

Nevett, L. (2010). Domestic Space in Classical Antiquity. Cambridge.

Nishimura-Jensen, J. M. (2000). 'Unstable geographies: the moving landcsape in Apollonius' Argonautica and Callimachus' Hymn to Delos', TAPA 130: 287-317.

Oikonomopoulou, K. (2017). 'Space, Delphi and the construction of the Greek past in Plutarch's Greek Questions, in: Georgiadou and Oikonomopoulou, 107-116.

Perutelli, A. (1994). 'Il sogno di Medea da Apollonio Rodio a Valerio Flacco', MD 33: 33-50.

Purves, A. C. (2010). Space and Time in Ancient Greek Narrative. Cambridge.

_ (2014). 'In the bedroom: interior space in Herodotus' Histories', in: Gilhuly and Worman, 94-129.

Reitz, Chr. (1996). Zur Gleichnistechnik des Apollonios von Rhodos. Studien zur klassischen Philologie 99. Frankfurt am Main.

Riggsby, A. (2009). 'Pliny in space (and time)', Arethusa 36: 167-86.

Robinson, D. M., and Graham, J. W. (1938). Excavations at Olynthus VIII. The Hellenic House. Baltimore. 
Rosen, R. M., and Sluiter, I. (eds.) (2004). City, countryside, and the spatial organization of value in classical antiquity. Mnemosyne Suppl. 279. Leiden.

Saïd, S. (2003). 'Divinations et devins dans les Argonautiques', in: Accorinti and Chuvin, 25575.

Schaaf, I. (2014). Magie und Ritual bei Apollonios Rhodios. Studien zu ihrer Form und Funktion in den Argonautika. Religionsgeschichtliche Versuche und Vorarbeiten 63. Berlin and Boston.

Souvatzi, S. G. (2008). A Social Archaeology of Households in Neolithic Greece: An Anthropological Approach. Cambridge.

Tally, R. T., Jr. (2013). Spatiality. Abingdon and New York.

Thalmann, W. G. (2011). Apollonius Rhodius and the Spaces of Hellenism. Oxford.

Thiel, K. (1993). Erzählung und Beschreibung in den Argonautika des Apollonios Rhodios. Ein Beitrag zur Poetik des hellenistischen Epos. Palingenesia 45. Stuttgart.

Trümper, M. (1998). Wohnen in Delos. Eine baugeschichtliche Untersuchung zum Wandel der Wohnkultur in hellenisticher Zeit. Internationale Archäologie 46. Rahden, Westf.

Tsagalis, C. (2012). From Listeners to Viewers: Space in the Iliad. Cambridge, Mass., and London.

Tuan, Y.-F. (1977). Space and Place: The Perspective of Experience. Minneapolis and London.

Ustinova, Y. (2009). Caves and the Greek Mind: Descending Underground in the Search for the Ultimate Truth. Oxford.

Vokotopoulou, J. (1996). Guide du Musée Archéologique de Thessalonique. Athens.

Werth, P. (1999). Text Worlds: Representing Conceptual Space in Discourse. London. 
Yuan, M. (2018). 'Human dynamics in space and time: a brief history and a view forward', Transactions in GIS 22: 900-12.

fig. 1 Attic r.-f. cup Brygos Painter (attr. by signature), Louvre G152: Briseis and Phoenix. https://commons.wikimedia.org/wiki/Category:Brygos_Painter\#/media/File:Briseis_Phoinix_Lo uvre G152.jpg 